\title{
PELATIHAN CORELDRAW DALAM MENINGKATKAN KETERAMPILAN WARGA BELAJAR PAKET C DI PKBM BINA MANDIRI LEMBAGA PEMASYARAKATAN NARKOTIKA CIPINANG JAKARTA TIMUR
}

\author{
Jaenal Mutakim \\ Universitas Negeri Jakarta \\ E-mail: jaenalmutakim@yahoo.com
}

\begin{abstract}
The research aims to understand understanding and improving skills for the study by analyzing study results given treatment to people learn in terms of cognitive, affective and in the improvement of psychomotor keterampilannya in learning tersebut.pelatihan ptning was something to build, supervise the independence and skill. The problem is the training doi has still not been able to build broader, insight mengtal attitude and independence that were lacking. Efforts are required to build training that can produce the: increased, insight and mental attitude and independence in the optimal guidance.

Methods used is a Experiment method. The research was conducted in pkbm bina independent correctional institution iia classes narcotics cipinang east jakarta in August 2012 - November 2012. As for the research is to be a human residents learn pkbm bina independent 10. residents learn as much asInstrument shaped pretest, research posttest, and the survey questionnaire. The validity of the test used was the validity of the contents of, while reabilitas using formulas product moment.Instrument used in the survey questionnaire where before has been done to test the validity of using formulas person product moment. The results of the recipe from 26 question contained a questionnaire is 1 question, declared invalid others expressed valid. We do reliability test measured by formula cronbach alpha until they reached the $r$ count $>\quad r$ table $=0.97>$ 0.632. the result can be concluded that there is increasing skill in understanding learning outcomes to provide training on coreldraw training to improve skills in the learning PKBM Bina Mandiri Lembaga Pemasyarakatan of the IIA Narcotics Cipinang East jakarta.
\end{abstract}

Keywords: Training , Coreldraw, Skills , PKBM, Correctional Institution

\begin{abstract}
Abstrak
Penelitian ini bertujuan untuk mengetahui pemahaman dan peningkatan keterampilan bagi warga belajar yaitu dengan menganalisis hasil belajar yang diberikan perlakuan (treatment) kepada warga belajar dilihat dari kognitif, afektif, dan psikomotorik dalam peningkatan keterampilannya dalam pembelajaran tersebut.Pelatihan merupakan hal ptning untuk membangun kemandirian dan keterampilan warga binaan. Masalahnya adalah pelatihan doi lokasi ini masih belum mampu membangun wawasan yang lebih luas, sikap mengtal dan kemandirian yang masih kurang. Diperlukan upaya untuk membangun pelatihan yang dapat menghasilkan adanya : peningkatan wawasan,dan sikap mental serta kemandirian yang optimal pada warga binaan.

Metode yang digunakan adalah metode experiment. Penelitian ini dilakukan di PKBM Bina Mandiri Lembaga Pemasyarakatan Klas IIA Narkotika Cipinang Jakarta timur pada bulan agustus 2012-bulan November 2012. Adapun yang menjadi sampel penelitian adalah warga belajar PKBM Bina Mandiri sebanyak 10 warga belajar. Instrument penelitian berbentuk pretest, posttest, dan angket (kuesioner). Validitas tes yang digunakan adalah validitas isi, sedangkan reabilitas menggunakan rumus product moment. Instrument yang digunakan berupa angket (kuesioner) dimana sebelumnya sudah dilakukan uji validitas dengan menggunakan rumus person product moment. Hasil rumus tersebut dari 26 pertanyaan yang terdapat kuesioner ada 1 pertanyaan yang dinyatakan tidak valid, yang lainnya dinyatakan valid. Kemudian dilakukan uji reliabilitas yang diukur dengan rumus Alpha Cronbach sehingga didapat hasil $\mathrm{r}$ hitung $>\mathrm{r}$ tabel $=0.97>0.632$. Dari hasil tersebut dapat disimpulkan adanya terdapat peningkatan keterampilan dalam pemahaman hasil belajar dalam memberikan pelatihan tentang pelatihan coreldraw
\end{abstract}


dalam meningkatkan keterampilan pada warga belajar PKBM Bina Mandiri Lembaga Pemasyarakatan Klas IIA Narkotika Cipinang Jakarta timur.

Kata Kunci : Pelatihan, Coreldraw, Keterampilan, PKBM, Lembaga Pemasyarakatan

\section{PENDAHULUAN}

Pendidikan merupakan kunci peningkatan mutu sumber daya manusia, Karena baik buruknya Negara dapat terlihat dari kualitas sumber daya manusia. Pemerintah telah berupaya melaksanakan wajib belajar 6 tahun sejak 1984 dan telah melaksanakan wajib belajar pendidikan dasar 9 tahun sejak tahun 1994. Menurut UU RI nomor 20 tahun 2003 tentang Sistem Pendidikan Nasional yang menyatakan "Pendidikan adalah usaha sadar terencana untuk mewujudkan suasana belajar dan proses pembelajaran agar peserta didik secara aktif mengembangkan potensi dirinya untuk memiliki kekuatan spiritual keagamaan, pengendalian diri, keperibadian, kecerdasan, akhlak mulia, serta keterampilan yang diperlukan dirinya, ma-syarakat, bangsa dan Negara." Menurut undang-undang sistem pendidikan Nasional No. 20 tahun 2003 pasal 26 ayat 1-4 menyebutkan arti dan fungsi pendidikan luar sekolah yaitu :

1. Pendidikan nonformal dianggap penting karena pendidikan luar sekolah diseleng-garakan bagi warga masyarakat yang memerlukan layanan pendidikan yang berfungsi sebagai pengganti, penambah, atau pelengkap pendidikan non formal dalam rangka mendukung pendidikan sepanjang hayat.

2. Pendidikan nonfomal berfungsi mengembangkan potensi peserta didik dengan penekanan pada penguasaan pengetahuan dan keterampilan fungsional serta pengembangan sikap dan kepribadian professional.

3. Satuan pendidikan nonformal terdiri atas lembaga kursus, lembaga pelatihan, kelompok belajar, pusat kegiatan belajar masyarakat dan majelis taklim serta satuan pendidikan yang sejenis.

Pusat Kegiatan Belajar Masyarakat atau disingkat PKBM merupakan pen-didikan nonformal yang memiliki dan dikelola oleh masyarakat atau orga-nisasi. Pemerintah berperan sebagai fasi-litator. PKBM adalah salah satu lembaga Pendidikan Luar Sekolah (PLS), yang tujuan dari keberadaannya adalah untuk membantu masyarakat dalam aspek ekonomi, budaya, social 
dalam meningkatakan alternative pendidikan yang dibutuhkan.

Pendidikan kesetaraan yang ada di PKBM adalah program pendidikan dasar pada jalur pendidikan nonformal bagi siapapun yang terkendala pada pendidikan formal atau berminat dan memilih pendidikan ksetaraan untuk ketuntasan pendidikan dasar. Adapun pendidikan kesetaraan meliputi : standar isi, standar proses pembelajaran, standar kompetensi lulusan, standar pen-didik dan tenaga kependidikan, standar sarana dan prasarana, standar penge-lolaan, standar pembiayaan, dan standar penilaian pendidikan.

Peranan PKBM disini berperan sebagai motor atau pengerak untuk mengadakan perubahan kognitif, afektif dan psiko-motorik warga bianaan untuk lebih meningkatkan sumber dayanya sebagai manusia. PKBM BINA MANDIRI terletak di Lembaga Pemasyarakatan Klas IIA Narkotika Jakarta, yang merupakan PKBM negeri yang didirikan oleh pemerintah. Pusat Kegiatan Belajar Masyarakat (PKBM) BINA MANDIRI adalah salah satu wadah Pendidikan Luar Sekolah bagi warga belajar yang teknis pendidikannya dibina oleh tenaga pendidik merupakan salah satu faktor dalam menunjang kelancaran kegiatan PKBM. Warga belajar yang terlibat dalam kegiatan pendidikan di PKBM BINA MANDIRI mayoritas mereka sebagai pe-langgar, walaupun memang ada warga belajar yang masih memiliki alasan mereka tidak mengikuti pembelajaran di dalam kelas karena aktifitas di dalam penjara mereka membutuhkan waktu yang sangat banyak dan tidak ada waktu jika mereka harus datang ke PKBM hanya untuk mengikuti pembelajaran.

Masalahnya adalah pada Kenyataannya kemampuan tiap-tiap warga belajar itu berbeda-beda. Ada warga belajar yang cepat dalam menyerap materi pelajaran, ada pula warga belajar yang lambat dalam menyerap materi pelajaran. Dalam perkembangan zaman sekarang teknologi semakin berkembang dan mereka membutuhkan pelajaran yang mudah dicerna dan di praktekan seperti keterampilan yang membuat mereka lebih dapat menyerap pelajaran. Oleh karena itu PKBM memliki ruang Lab. Komputer untuk mengembangkan keterampilan mereka dalam ber-karya inovasi dalam dunia Grafis. 
Pada saat kegiatan belajar di laksanakan mereka dapat mengembangkan keterampilannya dan akan menghasilakan keterampilan yang berdaya guna bagi mereka sendiri. Dengan belajar coreldraw mereka dapat membuat jenis gambar yang akan di jadikan brosur, pamplet, iklan, cetak photo, dan lain-lain.

Penelitian ini untuk mengetahui bagaimana efektifitas penerapan dalam pembelajaran grafis pelatihan coreldraw untuk meningkatkan kreaktivitas warga belajar di PKBM BINA MANDIRI Lembaga Pemasyarakatan Klas IIA Narkotika Jakarta.

\section{KAJIAN PUSTAKA}

\section{Pelatihan}

Pelatihan adalah proses sistematik perubahan prilaku para pegawai dalam suatu arah guna meningkatkan tujuan-tujuan organisasional. Dalam Pelatihan diciptakan suatu lingkungan dimana para pegawai dapat memperoleh atau mempelajari sikap dan keahlian dan perilaku yang spesifik yang berkaitan dengan pegawai. Disamping itu pe-latihan diberikan instsruksi untuk mengembangkan keahlian-keahlian yang dapat langsung terpakai pada pegawai, dalam rangka meningkatkan kinerja pegawai pada jabatan yang didudukinya sekarang.

Menurut Soekidjo Notoatmodjo yang dikutif dalam buku Pengembangan Sumber Daya Manusia menjelaskan bahwa: Pelatihan (training) adalah me-rupakan bagian dari suatu proses pen-didikan, yang tujuannya untuk mening-katkan kemampuan atau keterampilan khusus seseorang atau kelompok orang.

Pelatihan lebih berkaitan dengan peningkatan kemampuan atau keterampilan karyawan yang sudah menduduki suatu pekerjaan atau tugas tertentu. Dalam suatu pelatihan orientasi atau penekanannya pada tugas yang harus dilaksanakan, pelatihan pada umumnya menekankan kepada kemampuan psikomotor, meskipun didasari pengetahuan dan sikap.

Menurut Ikka Kartika A. Fauzi (2011), Pelatihan bertujuan untuk memperoleh tiga hal yaitu: menambah pengetahuan, menambah keterampilan dan merubah sikap. Pelatihan lebih menekankan pada pengembangan keahlian, pengetahuan dan sikap.

Pelatihan partisipatif didasarkan pada prinsip-prinsip sebagai berikut: 
1) Berdasarkan kebutuhan belajar (leraning needs based)

2) Berorientasi pada Tujuan Kegiatan Belajar (learning goals and objectives Oriented).

3) Berpusat pada warga belajar (participant Centered)

4) Belajar berdasarkan pengalaman (Experimential Learning).

Dari prinsip-prinsip tersebut nampak adanya keterlibatan peserta dalam perencanaan, keikutsertaan dalam peren-canaan pelakasanaan dan keikutsertaan dalam perencanaan evaluasi. Pelatih lebih beperan sebagai sumber belajar yang memfasilitasi peserta untuk men-capai tujuan pelatihan, yaitu perubahan penge-tahuan dan keterampilan.

Program pelatihan mempunyai tiga tahap aktivitas, (Barnardin \& Russell, yang mencakup:

1) Penilaian kebutuhan pelatihan (need Assesment),

2) Pengembangan program pelatihan (development),

3) Evaluasi program pelatihan (evaluation)

\section{CorelDraw}

Menurut Wahana Komputer dalam buku 25 Kreasi Grafis Popular dengan CorelDraw x6 menjelaskan definisi Coreldraw merupakan salah satu software pengolah gamabar yang dibuat oleh Corel Corporation yang berbasis vector. Dengan software ini dapat membuat berbagai macam kreasi desain grafis yang sangat popular akhir-kahir ini, misalnya brosur, spanduk, poster, kartu nama, desain souvenir, kalender, desain fashion, dan desain sticker dan masih banyak lagi.

Pada masa perkenalan, software Coreldraw telah menyediakan sejumlah besar alat pemroses objek gambar, mulai dari alat pembentukan objek gambar, hingga alat untuk presentasi. Berbagai kelengkapan fasilitas itulah yang membuat software coreldraw tidak tertandingi oleh software sejenis lainnya.

Keunggulan Coreldraw antara lain coreldraw sangat bagus dalam kolaborasi teks dan gambar. Selain itu kelebihan coreldraw yang jarang dimiliki oleh aplikasi desain grafis dengan mengolah gambar yang lain, sehingga kita bisa dengan mudah menemukan tutorial, tips dan bisa berbagi ilmu dengan pengguna coreldraw lainnya di seluruh dunia.

\section{Keterampilan}


Keterampilan merupakan bagian dari kompetensi. Keterampilan lahir dari ke-mampuan seseorang dalam melakukan suatu pekerjaan secara baik, dengan demikian orang tersebut dapat dikatakan cakap dalam bekerja.

Menurut buku Noor Fuad dan Gofur Ahmad dikutif dalam buku standar kompetensi nasional bidang teknologi informanika (Depdiknas RI,2003:4) disebutkan bahwa kompetensi adalah kemampuan melaksanakan tugas-tugas ditempat kerja yang mencakupi pe-nerapan keterampilan (skills) yang didukung dengan pengetahuan (cognitive) dan sikap (attitude) sesuai dengan kondisi yang dipersyaratkan. Keterampilan (skills) secara lebih luas diartikan oleh Ivancevich et. al. (1999;32) sebagai kemampuan atau kema-hiran di dalam melaksanakan tugas khusus. Menurut Ivancevich et.al., keterampilan yang harus dimiliki oleh seseorang, terutama pada karyawan yang berada pada tingkatan manajerial, yaitu sebagai berikut.

a. Keterampilan Teknis merupakan kemampuan untuk menggunakan pengetahuan spesifik, teknik-teknik, dan sumberdaya di dalam melaksanakan suatu pekerjaan.

b. Keterampilan Komputer merupakan kemampuan untuk mengoperasikan computer dan software pendukung pelaksanaan pekerjaan untuk menyelesaikan berbagai aspek pekerjaan secara lebih cepat, tepat, dan akurat.

c. Keterampilan membina hubungan merupakan kemampuan menjalin hubungan dengan orang lain, dalam melaksanakan pekerjaan secara bersama.

Berdasarkan uraian diatas dapat disimpulkan bahwa kompetensi adalah kemampuan seseorang dalam melaksanakan suatu aktivitas. Kemampuan itu merujuk pada beberapa karakteristik, baik yang bersifat dasar, perilaku, keterampilan, maupun pengetahuan dengan tingkat kemampuan yang dapat berubahubah. Perubahan tersebut bergantung pada seberapa jauh keterampilan, perilaku, dan pengetahuan tersebut.

\section{PKBM}

Pada awal pendiriannya PKBM me-rupakan pusat seluruh kegiatan belajar masyarakat dalam rangka peningkatan pengetahuan, keterampilan atau keahlian, hobi atau bakatnya yang 
dikelola dan diselenggarakan sendiri oleh masyarakat.

Latar Belakang berdirinya PKBM Bina Mandiri di Lembaga Pemasya-rakatan Klas IIA Narkotika Jakarta se-bagai kegiatan pendidikan luar sekolah, usaha sadar dalam mengembangkan se-luruh potensi yang ada dalam diri manusia untuk menjadi manusia yang seutuhnya.

Tujuan PKBM ialah meningkatkan pengetahuan, keterampilan, dan kemam-puan serta sikap masyarakat di sekitar PKBM secara layak dan berkembang melalui jalur pendidikan luar sekolah. Oleh karena itu, setiap warga belajar wajib mengikuti kegiatan pendidikan agar menjadi warga Negara yang bermutu dalam wawasan serta kemampuan untuk bersaing dimasya-rakat tak terkecuali para narapidana yang sedang menjalani hukuman di Lembaga Pemasyarakatan.

\section{Lembaga Permasyarakatan}

Lembaga Pemasyarakatan klas IIA Narkotika Jakarta adalah salah satu Lapas di Jakarta yang terletak di Kelurahan Cipinang Kecamatan Jatinegara Jakarta Timur. Berdiri diatas lahan seluas \pm 2.000 meter persegi, Lapas Narkotika Jakarta mempunyai 4 blok utama yaitu A, B, C dan Isolasi. Selain itu, tersedia ruang kantor, pendidikan, konsultasi, BLK serta ruang-ruang lain yang berkaitan dengan kegiatan pelatihan serta ketrampilan.

Lembaga pemasyarakatan Klas IIA Narkotika Jakarta adalah merupakan salah satu lembaga pemasyarakatan di Jakarta yang mempunyai tugas untuk membina para pelanggar hukum. seiring dengan meningkatnya kasus narkotika dari tahun ke tahun maka kapasitas di dalam Lapas Narkotika menjadi banyak dan melebihi daya tampungnya itu sendiri, sehingga permasalahan demi per-masalahan kerap terjadi di dalam Lembaga ini. Salah satu permasalahan yang ada dalam Lapas Narkotika Jakarta adalah program pembinaan yang tidak dapat mengakomodir seluruh narapidana yang seharusnya menjadi salah satu tujuan utama bagi seluruh Lapas di Indonesia.

$\begin{array}{rrrr}\text { Berbekal } & \text { UUD } & 1945 & \text { serta } \\ \text { undang-undang } & \text { no. } 12 & \text { tahun } & 1995\end{array}$
tentang pemasyarakatan dan peraturan pemerintah tentang pembinaan narapidana, maka Sejak diresmikan pada bulan Oktober tahun 2003 yang lalu, Lapas Narkotika Jakarta telah memulai operasinya dengan melaksanakan se- 
rangkaian program-program pembinaan bagi para narapidana khususnya narkotika dimana integrated system menjadi pilar utama kegiatan pembinaan khususnya dalam menyediakan pendidikan non-formal (Program Penyetaraan) bagi para narapidana putus sekolah sehingga dapat membantu mereka mengejar harapan untuk menjadi warga negara yang lebih baik seusai menjalani hukuman di Lembaga Pemasyarakatan.

\section{METEODOLOGI PENELITIAN}

Penelitian ini dilakukan untuk mengetahui pelatihan coreldraw dalam meningkatkan keterampilan pada warga belajar di PKBM Bina Mandiri Lembaga Pemasyarakatan Klas IIA Narkotika Jakarta.

Penelitian ini menggunakan metode penelitian eksperimen. Metode ini dipakai karena hasil penelitian dapat diketahui secara akurat, karena dapat mengetahui hasil dari setelah diberi perlakuan.

Populasi dalam penelitian ini melibatkan seluruh warga binaan yang mengikuti pelatihan coreldraw di PKBM Bina Mandiri Lembaga Pemasyarakatan Klas IIA Narkotika Jakarta Timur yang berjumlah 10 orang, Mengingat jumlah populasi tersebut juga dijadikan sebagai sampel penelitian.

Instrument yang digunakan dalam penelitian ini adalah angket/kuesioner. Jenis angket/kuesioner yang digunakan yaitu kuesioner tertutup yang diberikan kepada subyek, Instrumen ini dibuat berdasarkan tujuan penelitian yaitu untuk mengetahui hasil pelatihan coreldraw dalam upaya pembinaan di PKBM Bina Mandiri Lembaga Pemasyarakatan Klas IIA Narkotika Jakarta timur.

\section{HASIL DAN PEMBAHASAN}

Berdasarkan analisis diperoleh informasi bahwa Data yang dikumpulkan dari responden kemudian diolah, disusun dan dikelompokkan berdasarkan indicator penelitian yaitu proses pelatihan coreldraw dan keterampilan yang ditinjau dari segi kognitif, afektif dan psikomotorik.

Pada saat melaksanakan pelatihan coreldraw secara input melakasanakan Pretest sebelum pelatihan dilaksanakan untuk mengetahui seberapa paham kegunaan Aplikasi tersebut. Langkah kedua setelah mengetahui pemahaman warga belajar pada saat pelaksanaan pelatihan dimulai 
Jurnal Parameter Volume 30 No. 1 DOI : doi.org/10.21009/parameter.301.04

P-ISSN : 0216-261X E-ISSN : 2620-9519

dan menyertakan angket saat pelatihan,

posttest untuk mengetahui kemampuan kemudian akhir dari pelatihan coreldraw warga belajar dalam peningkatan dalam mengevaluasi hasil output dari keterampilan.

pelatihan menilai dengan menggunakan

Tabel 2.1. Kenaikan Hasil Pretest dan Posttest

\begin{tabular}{cccc}
\hline No. Res & Nilai Pretest & Nilai Posttest & Kenaikan \\
\hline 1. & 70 & 80 & 10 \\
\hline 2. & 60 & 70 & 10 \\
\hline 3. & 70 & 80 & 20 \\
\hline 4. & 50 & 70 & 15 \\
\hline $\mathbf{5 .}$ & 50 & 65 & 10 \\
\hline 6. & 70 & 80 & 15 \\
\hline 7. & 60 & 75 & 20 \\
\hline 8. & 70 & 90 & 15 \\
\hline 9. & 70 & 85 & 10 \\
\hline 10. & 80 & 90 & 13.5 \\
\hline Rata-rata & 65 & 78.5 & 15 \\
\hline
\end{tabular}

Setelah terhitung jumlah rata-rata maka hasil grafik sebagai berikut: kenaikan antara pretest dan posttest,

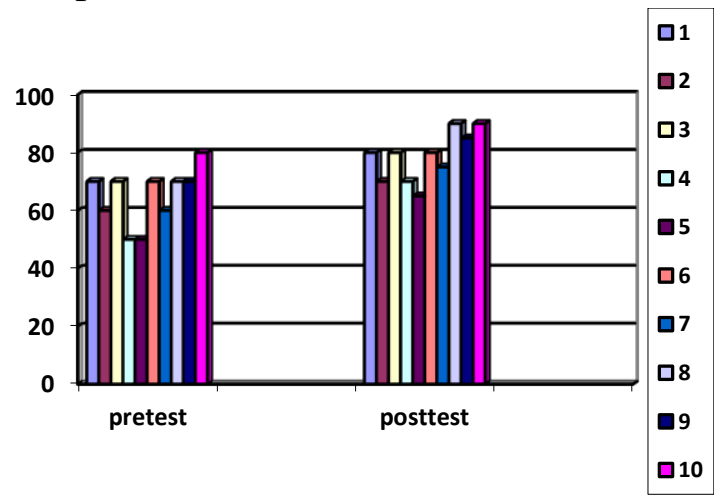

Gambar 4.1

Tabel Kenaikan Hasil Pretest dan Posttest 
Grafik tersebut menunjukan bahwa nilai post test mengalami kenaikan dari nilai pretest tersebut, ratarata hasil nilai pretest 65 dan nilai posttest 78.5 mengalami kenaikan 13,5. Untuk dapat mengetahui pema-haman peningkatan keterampilan pe-latihan coreldraw dalam menggambar / grafis dari nilai hasil pada saat pretest dan dari nilai hasil setelah dilakukan posttest tersebut.

\section{PENUTUP}

Berdasarkan data penelitian yang dilakukan peneliti baik dalam penyajian data maupun dalam meng-interprestasi data yang ada. Hal ini dikarenakan peneliti masih dalam tahap pembelajaran untuk menyampaikan hasil penelitian yang diperoleh dengan baik.

Pelatihan coreldraw yang dilaksanakan di Lembaga Pemasyarakatan Klas IIA Narkotika Jakarta. Dilihat dari proses dan keterampilan menunjukan hasil yang efektif, ditinjau dari segi proses pelatihan coreldraw, warga belajar mengikuti proses pelatihan mulai dari persiapan pelaksanaan pelatihan sampai hasil akhir pelatihan coreldraw. Warga belajar juga memiliki nilai yang cukup baik ketika diadakan tes menganai ke-mampuan menggunakan aplikasi corel-draw.

Keterampilan dapat dikatan berhasil dicapai, dimana tujuan pelatihan dapat terlaksana dengan baik yaitu membuat warga belajar dari tidak bisa meng-gunakan aplikasi coreldraw menjadi bisa menggunakannya. Pelatihan corel-draw juga berdaya guna baik untuk warga belajar itu sendiri maupun bagi orang lain.selama menjalani kehidupan di Lapas, warga belajar dapat mengem-bangkan keterampilannya untuk dapat dijadikan usaha penghasilannya.

Pembinaan yang dilakukan saat di Lapas tidak hanya sekedar untuk pengisi waktu luang saja, tapi harus memiliki pembekalan keterampilan bagi warga belajar. Dengan adanya pembinaan keterampilan bertujuan untuk menyiapkan warga belajar agar bisa secara lebih sehat ketika nanti sudah berada dilingkungan masyarakat serta dapat berperan aktif lagi sebagai warga yang baik dan bertanggung jawab.

\section{SARAN}

Berdasarkan hasil penelitian yang telah dipaparkan diatas maka saransaran yang dapat diberikan peneliti yaitu antara lain:

1. Bagi lembaga Pemasyarakatan Kelas IIA Narkotika Jakarta, penelitian ini diharapakan dapat memberikan masukan terhadap kekurangan-kekurangan yang mungkin terjadi dalam proses pembinaan pelatihan dalam memberikan keterampilan untuk mengembangkan kualitas yang ada.

2. Bagi Pembina/tutor/ pamong, perlu memberikan reward kepada yang rajin agar mereka lebih terpacu untuk mengukir prestasi kedepannya.

3. Memberikan pelatihan lagi kepada mereka angkatan baru yang akan 
mengikuti kegiatan pelatihan dengan mengadakan fasilitator pelatihan grafis agar materi yang terserap semakin banyak dan lebih baik.

\section{DAFTAR PUSTAKA}

Ambar T. Sulistiyani dan Rosidah. 2003. Manjemen Sumber Daya Manusia. Yogyakarta : Graha Ilmu.

Achmad S. Ruky. 2001 Sistem Manajemen Kinerja. Jakarta : Gramedia Pustaka Utama.

Haris Mujiman. 2007. Manajemen Pelatihan Berbasis Belajar Mandiri. Yogyakarta: Pustaka Pelajar, 2007

Ikka kartika A. Fauzi. 2011. Mengelola Pelatihan Partisipatif. Bandung: Alfabeta.

Noor Fuad dan Gofur Ahmad. 2009. Integrated human resources development, Jakarta : Grasindo.

Oemar hamalik. 2007. Manajemen Pelatihan Ketenagakerjaan Pendekatan Terpadu, Jakarta : Bumi Aksara.
Arikunto, S. 1985. prosedur penelitian, Jakarta : Bina Aksara.

Syahril Iskandar. 2006/2007. Aplikasi periklanan menggunakan Coreldraw x3. Jakarta : PT. Elex Media Komputindo.

Notoatmodjo, S. 2009. Pengembangan Sumber Daya Manusia. Jakarta : Rineka Cipta.

Sugiyono. 2009. Metode Penelitian Kuantitatif Kualitatif dan $R \& D$, Bandung : Alfabeta.

Pendidikan, PT. IMTIMA
Grafindo, 2007
,. 25 kreasi grafis popular dengan Coreldraw $x 6$. Yogyakarta : Andi Semarang : Wahana Komputer, 2012

Agil,Coreldraw.2012

(http://www.pusatgratis.com/ebookgratis/ebookkomputer/panduancoreldraw.html ), tgl 3 -11-2012 http://file.upi.edu/Direktori/SPS/PRODI .PENDIDIKAN_LUAR_SEK OLAH/196111091987031MUSTOFA_KAMIL/Bhaan_k uliah/PKBM_dan_model_Peng embangannya.pdf 